\title{
An optimal time incentive/disincentive-based compensation in contracts with multiple agents
}

\author{
S Mahdi Hosseinian
}

Bu-Ali Sina University, Iran

\begin{abstract}
This paper establishes an optimal time incentive/disincentive-based compensation in a contract between a principal and a team of agents. The establishment is based on solving an optimization problem. In order to validate the paper's theoretical development practitioners were engaged in a designed exercise. The paper demonstrates that, at the optimum: the proportion of time incentive/disincentive compensation among agents with the same risk-attitude should reflect the levels of their contributions; the proportion of time incentive/disincentive among agents with the same level of contribution should be lowered for agents with higher levels of risk aversion; and the proportion of time incentive/disincentive to a team of risk averse agents should reduce, and the fixed component of the team fee should increase, when the agents in the team become more risk-averse or the level of the uncertainty in project completion time increases. The paper's outcome provides guidance to those involved in contracts design for choosing the best way to reward (penalize) multiple agents, form a team, and allow for any time saving (overrun) through the terms of a contract.
\end{abstract}

Keywords: Time incentive/disincentive compensation, multiple agents, uncertainty, risk, contribution.

Paper type: Research article

\section{Introduction}

A multi-agent arrangement might be engaged by the principal (owner, client, investor) in large construction projects where extensive resources, skills and expertise are required (Ross, 2006). Entering foreign construction markets has also motivated the formation of a multi-agent arrangement, combining foreign and local firms. The term 'multi-agent arrangement' here refers to situations where a team of agents (for example in the form of consortia) is engaged by the principal for carrying out the principal's work. In such arrangements, project completion time is dependent on both the agents' effort and uncertainty in the completion time. This inevitably causes the agency problems because the agents' efforts (actions) cannot be fully monitored by the principal or a third party (e.g., court) due to information asymmetry and thus cannot be contractible. Putting in effort costs the agents and as such they may not provide the efforts that the principal desires, adversely affecting the project completion time (Eisenhardt, 1989).

To cope with this agency problem, also known as moral hazard problem, the principal may provide a time incentive/disincentive, in monetary units, to the agents as measured by project completion time expressed relative to a target time (Eisenhardt, 1989; Zhao, 2005; Hosseinian and Carmichael 2013a). The incentive aligns the agents' interests with those of the principal, but at the price of transferring risk of project completion time to the agents. The tradeoff between incentives and risk in determining a time incentive/disincentive arrangement is vital to the design of compensation with an incentive arrangement (Weitzman, 1980).

\footnotetext{
Copyright: Construction Economics and Building 2016. (C) 2016 S. Mahdi Hosseinian. This is an Open Access article distributed under the terms of the Creative Commons Attribution 4.0 Unported (CC BY 4.0) License (https://creativecommons.org/licenses/by/4.0/), allowing third parties to copy and redistribute the material in any medium or format and to remix, transform, and build upon the material for any purpose, even commercially, provided the original work is properly cited and states its license.
}

Citation: Hosseinian, S.M. 2016. An optimal time incentive/disincentive-based compensation in contracts with multiple agents. Construction Economics and Building, 16(4), 35-53. DOI: http://dx.doi.org/10.5130/AJCEB.v16i4.4983

Corresponding author: S. Mahdi Hosseinian; Email - s.hosseinian@basu.ac.ir

Publisher: University of Technology Sydney (UTS) ePress 
In construction literature, the notion of time incentive contracts is well established and discussions of such contracts date back to the early 1980s (Barnes, 1983). However, no publications exist investigating the time incentive problem in contracts with a team of agents, even though a team of agents (contractors, consultants), for example in the form of consortia, are commonly engaged for delivering large-scale projects. Inappropriate time incentive arrangements may reduce performance (Bresnen and Marshall, 2000) and may lead to allocating too much or providing little risk to the contracting parties (Chang, 2013) resulting in disagreements which eventually distort relationships among the parties (Rahman and Kumaraswamy, 2005). In the United Kingdom, as discussed by Chang (2013), a host of high-profile project failures are related to inappropriate incentive arrangements (see for example National Audit Office, 2009). Although risk management guides suggest that any risk associated with time underrun/overrun should be allocated to the party which can best manage it (Walewski and Gibson, 2003), in practice it is not always clear what is the optimal way to find the bearer of a risk source (Chang, 2013) and how far the risk can be transferred to the agent? Hughes et al. (2012), Chang (2013) and Hosseinian and Carmichael (2013a, b and 2014) all call for further research on a time incentive arrangement that is ideal for construction projects. This paper looks to fill the knowledge gap, and derives the optimal form of a time incentive/disincentive-based compensation in a construction contract between a principal and a team of agents. The derivation is based on solving an optimization problem. A time incentive/disincentive is established based on a sharing of a project's equivalent monetary time underrun/overrun (expressed relative to a benchmark or target time that is desired by the principal), while aligning the agents' interests with those of the principal. The paper provides new guidance to principals and agents on the best way to provide incentives for a team of agents for early project completion time or to penalize them for project overrun through the terms of a contract.

The rest of this paper is organized as follows. First, an exploration of current literature is provided. This is followed by a description of the time incentive problem. The theoretical results are then documented and subsequently tested in a designed exercise.

\section{Literature review}

Time incentive contracts are especially applicable in projects where the date of completion is important (Choi and Kwak, 2012). Abu-Hijlen and Ibbs (1989) argued that if early completion produces a sizable and early return on investment, the principal could afford to share a proportion of the expected benefits and create an incentive for the agent, one example being the use of time incentive contracts in highway projects which has helped to significantly reduce construction time (Arditi and Yasamis, 1998). Jaraiedi et al. (1995) pointed out that a project should be considered as a target time arrangement when, due to the safety of the community, road users, and/or the agent's employees, the project needs to be finished in the shortest possible time. Investigating the experience of U.S. highway agencies in incentives, Jaraiedi et al. (1995) concluded that incentive contracts work more effectively in reducing delivery time than in cutting costs.

A number of studies have examined time incentive arrangements in construction contracts typically where they apply to only one agent contracts. For example, Al-Subhi Al-Harbi (1998) used utility theory to explain how principals and agents determine the best incentive arrangement. Ward and Chapman (1994) argued that agents could nominate a time sharing value as part of their bid; and Sappington (1991) wrote of an iterative approach between the principal and the agent to establish the agent's incentive compensation. Alternatively, McGeorge and Palmer (2002) suggested that the allocation of a monetary incentive should be $50 \%$ of the saving to the principal due to the time underrun and $50 \%$ to the other parties to the project; divided proportionately to each of the other parties' contributions. 
Perry and Barnes (2000) suggested avoiding a proportion of time risk sharing to the agent less than 50\%. Broome and Perry (2002) concluded that there is need for research on the interaction of risk and the selection of an incentive arrangement. Love et al. (2011) argued 50:50 time risk sharing underpins the equality of the principal and agent relationship. Badenfelt (2008) identified three factors influencing the choice of the proportion of incentive to the agent, namely perception of fairness, knowledge of target and long-term relationships. To develop a proper incentive arrangement, Badenfelt (2008) recommended that the contracting parties collect trustworthy data about each other's skills, reputation and target time. Based on a survey, Chan et al. (2011) suggested that any time incentive arrangement should be established based on risk control ability of both agent and client. Hosseinian and Carmichael (2013a, b and 2014) addressed the optimal incentive problem in construction projects with a single agent. Using principal-agent theory Chang (2013) investigated the consequence of contract breakup into risk allocation decisions.

Table 1: Related research for optimal time sharing in contracts

\begin{tabular}{|c|c|c|c|c|c|}
\hline $\begin{array}{l}\text { Area of } \\
\text { Studies }\end{array}$ & Method & Methodology & Advantages & Limitations & Reference \\
\hline Economics & $\begin{array}{l}\text { Theoretical } \\
\text { investigation }\end{array}$ & $\begin{array}{l}\text { Principal-agent } \\
\text { theory }\end{array}$ & $\begin{array}{l}\text { Developing } \\
\text { optimal } \\
\text { incentive } \\
\text { contracts }\end{array}$ & $\begin{array}{l}\text { Lack of empirical } \\
\text { research; considering one } \\
\text { agent contracts }\end{array}$ & $\begin{array}{l}\text { Holmstrom } \\
(1979) ; \\
\text { Holmstrom } \\
\text { and Milgrom } \\
\text { (1987); }\end{array}$ \\
\hline \multirow[t]{7}{*}{$\begin{array}{l}\text { Construction } \\
\text { and project } \\
\text { management }\end{array}$} & $\begin{array}{l}\text { Theoretical } \\
\text { investigation }\end{array}$ & Utility theory & $\begin{array}{l}\text { Proposing a risk } \\
\text { sharing model }\end{array}$ & $\begin{array}{l}\text { Lack of empirical } \\
\text { research; considering one } \\
\text { agent contracts; ignoring } \\
\text { optimal time sharing }\end{array}$ & $\begin{array}{l}\text { Al-Subhi Al- } \\
\text { Harbi (1998) }\end{array}$ \\
\hline & $\begin{array}{l}\text { Theoretical } \\
\text { investigation }\end{array}$ & Discussion & $\begin{array}{l}\text { Suggesting a } \\
\text { proportion of } \\
\text { time risk sharing } \\
\text { to the agent } \\
\text { more than } 50 \%\end{array}$ & $\begin{array}{l}\text { Lack of empirical } \\
\text { research; ignoring agents } \\
\text { risk attitudes and } \\
\text { outcome uncertainties; } \\
\text { considering one agent } \\
\text { contracts; ignoring } \\
\text { optimal time sharing }\end{array}$ & $\begin{array}{l}\text { Perry and } \\
\text { Barnes (2000) }\end{array}$ \\
\hline & $\begin{array}{l}\text { Theoretical } \\
\text { investigation }\end{array}$ & $\begin{array}{l}\text { Principal-agent } \\
\text { theory }\end{array}$ & $\begin{array}{l}\text { Analyzing risk- } \\
\text { sharing }\end{array}$ & $\begin{array}{l}\text { Lack of empirical } \\
\text { research; considering one } \\
\text { agent contracts, ignoring } \\
\text { optimal time sharing }\end{array}$ & Chang (2013) \\
\hline & $\begin{array}{l}\text { Theoretical } \\
\text { and } \\
\text { empirical } \\
\text { investigation }\end{array}$ & $\begin{array}{l}\text { Agency theory, } \\
\text { interviews }\end{array}$ & $\begin{array}{l}\text { Proposing } \\
\text { optimal } \\
\text { incentive } \\
\text { contracts }\end{array}$ & $\begin{array}{l}\text { Considering one agent } \\
\text { contracts; ignoring } \\
\text { optimal time sharing }\end{array}$ & $\begin{array}{l}\text { Hosseinian } \\
\text { and } \\
\text { Carmichael } \\
\text { (2013a, b and } \\
2014)\end{array}$ \\
\hline & $\begin{array}{l}\text { Empirical } \\
\text { investigation }\end{array}$ & $\begin{array}{l}\text { Alliance } \\
\text { contracting; } \\
\text { interviews }\end{array}$ & $\begin{array}{l}\text { Proposing a risk } \\
\text { sharing model }\end{array}$ & $\begin{array}{l}\text { Ignoring agents risk } \\
\text { attitudes and project time } \\
\text { uncertainties }\end{array}$ & $\begin{array}{l}\text { Love et al. } \\
\text { (2011) }\end{array}$ \\
\hline & $\begin{array}{l}\text { Empirical } \\
\text { investigation }\end{array}$ & $\begin{array}{l}\text { Questionnaire } \\
\text { survey }\end{array}$ & $\begin{array}{l}\text { Presenting the } \\
\text { effects of some } \\
\text { factors on } \\
\text { incentive } \\
\text { contracts }\end{array}$ & $\begin{array}{l}\text { Considering one agent } \\
\text { contracts; ignoring } \\
\text { optimal time sharing }\end{array}$ & $\begin{array}{l}\text { Badenfelt } \\
(2008)\end{array}$ \\
\hline & $\begin{array}{l}\text { Empirical } \\
\text { investigation }\end{array}$ & $\begin{array}{l}\text { Questionnaire } \\
\text { survey }\end{array}$ & $\begin{array}{l}\text { Developing a } \\
\text { risk sharing } \\
\text { model }\end{array}$ & $\begin{array}{l}\text { Considering one agent } \\
\text { contracts; ignoring } \\
\text { optimal time sharing }\end{array}$ & $\begin{array}{l}\text { Chan et al. } \\
\text { (2011) }\end{array}$ \\
\hline
\end{tabular}

Despite an extensive body of publications on time incentive contracts, a review of the literature, as shown in Table 1, reveals that few studies have examined the influence of factors affecting the choice of a time incentive arrangement (Al-Subhi Al-Harbi, 1998; Broome and Perry, 2002; Badenfelt, 2008; Hosseinian and Carmichael, 2013a, b and 2014). No literature appears to have 
focused on the optimal time incentive compensation arrangement in contracts with multiple agents. In light of this, this paper gives original derivation for optimal time incentive compensation arrangements in construction multi-agent contracts. The derivation is based on solving an optimization problem using concepts from agency theory; a theory with roots in economics literature. This theory provides a useful insight into the incentive problem (Eisenhardt, 1989) and is relevant to the study of construction. While the theory developed in this paper can be applied, with little modification, to any part of the project work, the attention is mostly limited to the whole project for the relative important of project completion time.

It is noticed that a sharing arrangement may be applied to more than one project outcome (cost, time, quality and so on) particularly in alliance projects when the principal is concerned about more than one project outcome (Ross, 2006). By contrast, this paper focuses solely on the optimal form of a time sharing arrangement. When the sharing applies to more than one project outcome, selecting an optimal sharing arrangement becomes more complicated. Although some studies have looked at multiple outcome sharing (Sakal, 2005; Love et al., 2011) choosing an appropriate sharing arrangement to date has not been based on scientifically sound evidence or mathematical calculation (Badenfelt, 2008). Previous research has stressed that the sharing arrangement should be fair (Bower et al., 2002; Badenfelt, 2008; Love et al., 2011), though how fair and unfair are defined is undetermined in construction contracts. This paper gives guidance on the setting of time sharing in contracts with multi-agent arrangements.

\section{Problem description}

The time incentive problem can be formulated as a constrained optimization problem using idea from agency (principal-agent) theory (Holmstrom and Milgrom, 1987). Consider a team of agents (contractors, consultants) is engaged by the principal (owner, client) (for example in the form of a consortia) to perform a task (for example to carry out a project) and the principal is concerned about the task time/duration (for example project completion time). The principal is not able to fully monitor the effort (action) of the agents (hard-working or shirking) due to asymmetric information (Petersen, 1993); the agents are potentially able to extend the time a job takes by shirking or not working effectively as the principal does not have any access to such information. As the agents' efforts cannot be verified by a third party and thus cannot be contracted on and also as the agents' efforts are costly, the agents might not put the necessary level of effort required by the principal leading to an undesired outcome, for example late project completion. To overcome this problem, known as the moral hazard problem (Holmstrom, 1979), the principal might provide a time incentive contract to the agents based on sharing the monetary value of time underrun (early completion saving) while penalizing the agents for any cost to the principal due to time overrun (late completion cost) relative to a target duration (Laffont and Martimort, 2001). This contract needs to maximize the principal's expected utility, while ensuring that the agents agree to the contractual arrangement and the agents provide acceptable effort levels for the principal; this defines the objective function and the constraints to the optimization problems.

The time incentive problem involving a team of agents typically exists in two components (Holmstrom and Milgrom, 1987; Lambert, 2001). The first is how to provide time incentives to the team. The second is how to distribute the team's incentive among the agents within the team. A possible time incentive compensation with a team of two agents, $i=1$ (Agent $A$ ) and $i=2$ (Agent B), may determine the agents' fees based on a target time contract according to,

$$
\mathrm{Fee}_{\mathrm{i}}=\mathrm{F}_{\mathrm{i}}+\mathrm{s}_{\mathrm{i}}(\mathrm{Tt}-\mathrm{At}) \mathrm{k} \quad \mathrm{i}=1,2
$$

where $F_{i}$ is a fixed component of an agent's fee; $s_{i}$ is a (risk) sharing ratio for agent $i$, taking values in the range 0 to 1; Tt is a target time estimate of the project; At is the actual time of the project; and $\mathrm{k}$ converts time units to cost units; for example, late completion in contracts is reflected by 
the amount inserted in the contract for liquidated damages. Upper and lower limits can be additionally placed on the fee. The agent's fee goes up or down depending on the actual time. For time overruns, the fee is adjusted down (disincentive); for actual time less than estimated, the fee is adjusted up (incentive). It might be noted that Equation (1) focuses on contracts in which the agent's fee is a linear function of output (actual time). Although a nonlinear payment may lead to a better outcome for the principal, the linear class of payment is studied for the following reasons. Firstly, simulation-based research has shown that the difference in results arising from the use of a linear payment assumption is relatively small (Basu and Kalyanaram, 1990; Raju and Srinivasan, 1996). Secondly, it is straightforward to implement managerially. Finally, the choice of a linear payment assumption is consistent with that of Holmstrom and Milgrom (1987), who show that linear payments may indeed be the optimal form where agents continuously influence effort and observe output.

Care has to be exercised in establishing the target time estimate. Too high a time estimate is easy for the agent to achieve, too low an estimate is hard to achieve. In order to deal with this issue, the target estimate can be agreed by the parties, or established by a third independent party (Hosseinian and Carmichael, 2013a).

The sum of the agents' fees is the total fee paid by the principal to the agents' team. Accordingly, the team's fee can be given by,

$$
\text { Fee }=\sum_{\mathrm{i}=1}^{2} \mathrm{~F}_{\mathrm{i}}+\sum_{\mathrm{i}=1}^{2} \mathrm{~s}_{\mathrm{i}}(\mathrm{Tt}-\mathrm{At}) \mathrm{k}=\mathrm{F}+\mathrm{s}(\mathrm{Tt}-\mathrm{At}) \mathrm{k}
$$

where $\mathrm{F}$ is a fixed component of the team's fee, and $\mathrm{s}$ is the team's (risk) sharing ratio, taking values in the range 0 to 1 ,

$$
\mathrm{S}=\sum_{\mathrm{i}=1}^{2} \mathrm{~s}_{\mathrm{i}} \leq 1
$$

The principal's problem is to offer a time incentive contract to a team of agents with a fee defined as in Equations (1) and (2) to maximize the principal's expected utility. This contract needs to include a minimum fee required to motivate the agents to agree to the contractual arrangement. The contract also needs to maximize the agents' expected utility to motivate the agents to select the effort levels favored by the principal (both interpreted as constraints).

\section{Proposed optimization problem}

The following derives the optimal form of a time incentive/disincentive contract under defined risk assumptions on the agents (risk averse ranging to risk neutral) and the principal (risk neutral). This is particularly relevant when a large principal organization, which may likely be risk-neutral, engages a team of risk averse contractors to perform work.

Let us assume the project time underrun/overrun is dependent on the agents' efforts, denoted by $e_{i}$, and events which are outside of the agents' influence, allowed for through a noise term, denoted by $\varepsilon$, representing the uncertainty in actual time. $\varepsilon$ is assumed to be normally distributed with a mean of zero and variance $\sigma^{2}$ in accordance with agency literature (Holmstrom and Milgrom, 1987). For the purpose of this paper it is also assumed that all agents have the appropriate skills, and that the project time underrun/overrun varies linearly with effort, e, giving,

$$
(\mathrm{Tt}-\mathrm{At}) \mathrm{k}=\sum_{\mathrm{i}=1}^{2} \psi_{\mathrm{i}} \mathrm{e}_{\mathrm{i}}+\varepsilon
$$


The constant coefficient $\psi_{\mathrm{i}}$ represents the contribution of agent $\mathrm{i}$ towards the project completion time. An agent's contribution level might be based on that agent's expenditure as a proportion of the total team cost (Ross, 2006; Love et al., 2011). However, where expenditure does not properly reflect the relative influence of each agent on the project completion time, the value used for contribution level can be adjusted (Ross, 2006). The linearity assumption is not critical, rather it simplifies the mathematical manipulation. Coughlan and Sen (1989) demonstrate that this linearity assumption does not involve much loss of generality.

The agent's fee, denoted as Fee, is taken as being dependent on the project completion time as given by Equations (1) and (2).

The principal enjoys the monetary value of time saving, (Tt-At), but has to pay the agents' fee. Therefore, the principal's utility (or payoff), in monetary units, is the difference between the monetary value of time saving received and the fee paid. The principal is assumed here to be riskneutral. Using Equations (1) and (4), and the notation $E\left[\mathrm{U}_{\mathrm{p}}\right]$ to denote expected value, the expected utility of the principal is given by,

$$
E\left[U_{P}\right]=\left(1-\sum_{i=1}^{2} n_{i}\right)\left(\sum_{i=1}^{2} \psi_{i} e_{i}\right)-\sum_{i=1}^{2} F_{i}
$$

The agents receive their fees, and apply effort, but incur costs. Let $\mathrm{C}_{\mathrm{i}}\left(\mathrm{e}_{\mathrm{i}}\right)$ be the monetary disutility of action (effort level, $\mathrm{e}_{\mathrm{i}}$ ) that cannot be charged to the project.

The agents are assumed to be risk-averse (including risk neutral as an extreme), with utility defined in terms of the agent's level of satisfaction arising from a change in the wealth level, denoted by, $\pi$,

$$
\mathrm{U}_{\mathrm{i}}\left(\pi_{\mathrm{i}}\right) \quad \mathrm{i}=1,2
$$

Here the wealth level $(\pi)$ can be defined as the difference between the fee received and the cost of the agents' effort,

$$
\pi_{\mathrm{i}}=\mathrm{Fee}_{\mathrm{i}}-\mathrm{C}_{\mathrm{i}}\left(\mathrm{e}_{\mathrm{i}}\right) \quad \mathrm{i}=1,2
$$

The agents are normally assumed to have a concave utility function to reflect the agent's aversion to risk taking. Exponential, power and linear-exponential are candidate functions (Kirkwood, 2004). The exponential utility function is a popular choice in the modeling (Holmstrom and Milgrom, 1987; Kirkwood, 2004), and for the agents has the form,

$$
\mathrm{U}_{\mathrm{i}}\left(\mathrm{Fee}_{\mathrm{i}}-\mathrm{C}_{\mathrm{i}}\right)=1-\exp \left[-\eta_{\mathrm{i}} \times\left(\mathrm{Fee}_{\mathrm{i}}-\mathrm{C}_{\mathrm{i}}\right)\right] \quad \mathrm{i}=1,2
$$

where $\eta_{\mathrm{i}}$ is the level of risk aversion. As $\eta$ becomes smaller, the utility function displays less risk aversion; when $\eta$ is zero, the agent becomes risk-neutral.

\section{Optimization components}

The agents wish to maximize their expected utility through the choice of effort, e. Maximizing the expected utility itself can arrive at the same result as maximizing the certainty equivalent of the contract (Clemen and Reilly, 2001). A certainty equivalent is a fee that is the same in the agent's mind to a corresponding situation that involves uncertainty, and equals the expected fee minus the cost of its effort, $\mathrm{C}_{\mathrm{i}}\left(\mathrm{e}_{\mathrm{i}}\right)$, minus a risk premium.

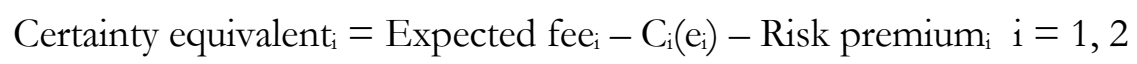

A risk premium is defined as the cost of the risk borne by the agent depending on the variance of its fee and how risk-averse it is. Barnes (1983) argues that agents often assess the expected cost of the work and then add a single risk premium associated with the size of the total risk being borne. 
For obtaining the risk premium, a suitable approximation is discussed in Clemen and Reilly (2001) and Kirkwood (2004). It is given by,

$$
\text { Risk Premium }_{\mathrm{i}}=\frac{\mathrm{s}_{\mathrm{i}}^{2} \eta_{\mathrm{i}} \sigma^{2}}{2} \quad \mathrm{i}=1,2
$$

where $\sigma^{2}$ is variance of the monetary value of time underrun/overrun.

The expected fee to each agent can be obtained by substituting Equation (4) into Equation (1), while noting that $\mathrm{E}[\mathrm{\varepsilon}]=0$,

$$
\mathrm{E}\left[\mathrm{Fee}_{\mathrm{i}}\right]=\mathrm{F}_{\mathrm{i}}+\mathrm{s}_{\mathrm{i}} \psi_{\mathrm{i}} \mathrm{e}_{\mathrm{i}}
$$

Following Holmstrom and Milgrom $(1987,1991)$ and Feltham and Xie (1994), each agent's cost function $\mathrm{C}_{\mathrm{i}}\left(\mathrm{e}_{\mathrm{i}}\right)$ is assumed to raise with $\mathrm{e}_{\mathrm{i}}$ at an increasing rate. The simplest functional form that meets this requirement can be written as,

$$
\mathrm{C}_{\mathrm{i}}\left(\mathrm{e}_{\mathrm{i}}\right)=\frac{\mathrm{m}_{\mathrm{i}}}{2} \mathrm{e}_{\mathrm{i}}^{2}
$$

where $\mathrm{m}$ is a coefficient converting units of effort ${ }^{2}$ to monetary units.

Substituting Equations (9), (10) and (11) in (8), the certainty equivalents corresponding to the agents' expected utilities can be given by,

$$
\mathrm{CE}_{\mathrm{i}}=\mathrm{F}_{\mathrm{i}}+\mathrm{s}_{\mathrm{i}}\left(\sum_{\mathrm{i}=1}^{2} \psi_{\mathrm{i}} \mathrm{e}_{\mathrm{i}}\right)-\frac{\mathrm{m}}{2} \mathrm{e}_{\mathrm{i}}^{2}-\frac{\mathrm{s}_{\mathrm{i}}^{2} \psi_{\mathrm{i}} \sigma^{2}}{2} \quad \mathrm{i}=1,2
$$

The principal's problem is to offer a contract to the agents' team with a fee, defined in Equation (2), in order to maximize its expected utility, see Equation (5),

$$
\operatorname{Max}_{\mathrm{s}_{1}, \mathrm{~s}_{2}, \mathrm{~F}_{1}, \mathrm{~F}_{2}}\left(1-\sum_{\mathrm{i}=1}^{2} \mathrm{~s}_{\mathrm{i}}\right)\left(\sum_{\mathrm{i}=1}^{2} \psi_{\mathrm{i}} \mathrm{e}_{\mathrm{i}}\right)-\sum_{\mathrm{i}=1}^{2} \mathrm{~F}_{\mathrm{i}}
$$

This contract needs to include a minimum fee, MinFee, required by each agent to motivate the agents to agree to the contractual arrangement,

$$
\mathrm{F}_{\mathrm{i}}+\mathrm{s}_{\mathrm{i}}\left(\sum_{\mathrm{i}=1}^{2} \psi_{\mathrm{i}} \mathrm{e}_{\mathrm{i}}\right)-\frac{\mathrm{m}}{2} \mathrm{e}_{\mathrm{i}}^{2} \geq \text { Min fee }_{\mathrm{i}}
$$

Each agent selects the effort level that maximizes its certainty equivalent. As a consequence, the effort level favored by the principal needs to maximize the agent's certainty equivalent,

$$
\underset{\mathrm{e}_{\mathrm{i}}}{\operatorname{Max}} \mathrm{F}_{\mathrm{i}}+\mathrm{s}_{\mathrm{i}}\left(\sum_{\mathrm{i}=1}^{2} \psi_{\mathrm{i}} \mathrm{e}_{\mathrm{i}}\right)-\frac{\mathrm{m}}{2} \mathrm{e}_{\mathrm{i}}^{2}-\frac{\mathrm{s}_{\mathrm{i}}^{2} \psi_{\mathrm{i}} \sigma^{2}}{2} \quad \mathrm{i}=1,2
$$

Expressions (14) and (15) represent the constraints of the proposed optimization problem. The first constraint (14) is called the individual rationality constraint (Kraus, 1996). The second constraint (15) is called the incentive compatibility constraint. Its purpose is to motivate the agents to behave in the principal's interest. The incentive compatibility constraint reflects the restriction whereby the principal can observe the agents' outcome (project time underrun/overrun) but not their efforts (Kraus 1996). Expressions (13), (14) and (15) constitute the optimization problem. 


\section{Optimization results}

Differentiating expression (12) with respect to $\mathrm{e}_{\mathrm{i}}$ and setting it to zero provides the optimal level of effort (denoted by *),

$$
\mathrm{e}_{\mathrm{i}}^{*}=\frac{\psi_{\mathrm{i}}}{\mathrm{m}} \mathrm{s}_{\mathrm{i}} \quad \mathrm{i}=1,2
$$

It follows that, at the optimum, the principal does not need to pay the agents more than the minimum fee required by the agents to agree to the contractual arrangement. Thus, the optimal value of $\mathrm{F}_{\mathrm{i}}$ would be such that expression (14) holds as an equality, that is,

$$
\mathrm{F}_{\mathrm{i}}^{*}=\text { Min fee }_{\mathrm{i}}-\mathrm{s}_{\mathrm{i}}\left(\sum_{\mathrm{i}=1}^{2} \psi_{\mathrm{i}} \mathrm{e}_{\mathrm{i}}\right)+\frac{\mathrm{m}}{2} \mathrm{e}_{\mathrm{i}}^{2}+\frac{\psi_{\mathrm{i}}^{2} \eta_{\mathrm{i}} \sigma^{2}}{2} \quad \mathrm{i}=1,2
$$

Substituting Equations (16) and (17) into (13), and simplifying it, the principal's problem can be rewritten as,

$$
\operatorname{Max}_{\mathrm{s}_{1}, \mathrm{~s}_{2}}\left(\sum_{\mathrm{i}=1}^{2} \frac{\psi_{\mathrm{i}}^{2}}{\mathrm{~m}} \mathrm{~s}_{\mathrm{i}}\right)-\sum_{\mathrm{i}=1}^{2}\left(\operatorname{Minfee}_{\mathrm{i}}+\frac{\psi_{\mathrm{i}}^{2}}{2 \mathrm{~m}} \mathrm{~s}_{\mathrm{i}}^{2}+\frac{\psi_{\mathrm{i}}^{2} \eta_{\mathrm{i}} \sigma^{2}}{2}\right)
$$

Differentiating expression (18) with respect to $n_{i}$ and setting it to zero provides the optimal sharing ratio,

$$
\mathrm{s}_{\mathrm{i}}^{*}=\frac{1}{1+\frac{\eta_{\mathrm{i}} \sigma^{2} \mathrm{~m}}{\psi_{\mathrm{i}}^{2}}} \quad \mathrm{i}=1,2
$$

Equation (19) generally shows that $s_{i}^{*} \geq s_{j}^{*}$ if $\psi_{i} / \eta_{i} \geq \psi_{j} / \eta_{j}$ and $s_{i}^{*} \leq s_{j}^{*}$ if $\psi_{i} / \eta_{i} \leq \psi_{j} / \eta_{j}$, where $i$ and $j$ represent any two of the $n$ agents within the team.

Substituting Equation (19) into (17), leads to the optimal fixed components of an agents fee,

$$
\begin{aligned}
& \mathrm{F}_{1}^{*}=\mathrm{F}_{\min _{1}}-\frac{\psi_{1}^{2}}{2 \mathrm{~m}} \mathrm{~s}_{1}^{* 2}-\frac{\psi_{2}^{2}}{\mathrm{~m}} \mathrm{~s}_{1}^{*} \mathrm{~s}_{2}^{*}+\frac{1}{2} \mathrm{~s}_{1}^{* 2} \eta_{1} \sigma^{2} \\
& \mathrm{~F}_{2}^{*}=\mathrm{F}_{\text {min }_{2}}-\frac{\psi_{2}^{2}}{2 \mathrm{~b}} \mathrm{~s}_{2}^{* 2}-\frac{\psi_{1}^{2}}{\mathrm{~m}} \mathrm{~s}_{1}^{*} \mathrm{~s}_{2}^{*}+\frac{1}{2} \mathrm{~s}_{2}^{* 2} \eta_{2} \sigma^{2}
\end{aligned}
$$

where $\mathrm{F}_{\text {min }_{\mathrm{i}}}$ is the minimum fee required by agent $\mathrm{i}$ to motivate them to agree to the contractual arrangement.

Based on Equations (19), (20a) and (20b), the optimal time incentive/disincentive contract with a team of risk averse agents is obtained by using,

$$
\text { Fee }=\sum_{i=1}^{2} F_{i}^{*}+\sum_{i=1}^{2} s_{i}^{*}(T t-A t) k=F^{*}+s^{*}(T t-A t) k
$$

In practice, a risk cap may be set by some agents so that a small return margin or zero loss is guaranteed to the agents; however, this can lead to extra costs for the principal (Carmichael, 2000; Love et al., 2011). 


\section{The development of propositions}

\section{Sharing monetary value of time underrun/overrun among agents}

Equation (19) demonstrates that in the case where agents have the same level of risk aversion, namely $\eta_{1}=\eta_{2}$, but different levels of contribution in the project, that agent with a higher level of contribution should receive/bear a higher proportion of monetary value of time underrun/overrun (incentive/disincentive). This leads to the following proposition.

Proposition 1. The proportion of monetary value of time incentive/disincentive among agents (in a team), with the same level of risk aversion, needs to be higher for agents with a higher contribution to the project.

Equation (19) also shows that in the case where agents have the same level of contribution in the project, namely $\psi_{1}=\psi_{2}$, but different levels of risk aversion, that the agent with a higher level of risk aversion should receive/bear a lower proportion of monetary time underrun/overrun (incentive/disincentive). This leads to the second proposition.

Proposition 2. The proportion of monetary value of time incentive/disincentive among agents (in a team), with the same level of contribution, needs to be lower for agents with higher levels of risk aversion.

\section{Sharing monetary value of time underrun/overrun between principal and agents' team}

Based on Equation (19), where the agents' levels of risk aversion increase or the level of uncertainty in the project time increases, the team's share of the monetary value of time underrun/overrun needs to decrease in order to contain the cost of the risk borne by the agents (risk premium). This leads to the third proposition.

Proposition 3. The proportion of monetary value of time incentive/disincentive to a team of risk-averse agents needs to reduce (3a) with increasing uncertainty level in the project time, or (3b) with increasing agent risk aversion.

Based on Equations (20a) and (20b), to motivate risk-averse agents to accept the contract, the agent team's fixed fee, $\mathrm{F}$ in Equation (2), needs to increase as the time uncertainty or risk aversion levels of the agents increase. This leads to the last proposition.

Proposition 4. With a team of risk-averse agents, the team's fixed fee needs to increase (4a) with increasing time uncertainty, or (4b) with increasing agent risk aversion.

\section{Empirical support for the theoretical results-outline}

\section{Agent sample}

In order to provide empirical support for the above theoretical results, an empirical study was conducted on a sample of mid-sized construction contractors (agents) in Iran whose work is generally commercial building and industrial projects in the approximate range \$5-15 million; this covers the cost of most buildings in Iran. Senior staff members (one from each organization represented), engaged in contracts on behalf of these organizations, were asked to make decisions as representatives of their organizations; that is, as corporate decision-makers, not as private individuals dealing with their own funds. A random sample of 70 contractor organizations were contacted for the interview, of which 48 participated in the research. The appropriateness of a small-sample size is not an uncommon issue in construction management studies. For instance, the sample size of the earlier research of Love et al. (2011) and Badenfelt (2008) were 29 and 16, respectively. All participants in this study were experienced construction practitioners; $43.8 \%$ of the participants had more than 21 years of experience in the construction industry, and $33.4 \%$ of 
the participants between 11 and 20 years, as illustrated in Table 2. The number of projects in which the participants have been involved is considerable as shown in Table 2; 43.75\% of the contractors were engaged in more than 26 projects, $47.92 \%$ of the contractors between 5 and 25 projects and the rest $(8.33 \%)$ less than 5 projects. The participants' positions in their organizations are shown in Table 2. Due to the considerable experience of the participants, induction based on their responses can be regarded as very persuasive. Although primary reference is to construction projects and contractors, the solutions presented here apply equally to other agents (consultants) and related project types. Before interviewing participants, a pilot interview study, fine-tuning and validation of the interview questions was conducted with a number of experienced project managers from contractor organizations.

Table 2: Experience, involvement in projects and positions of the participants in the study

\begin{tabular}{|c|c|c|c|c|c|c|c|c|}
\hline $\begin{array}{l}\text { Experience } \\
\text { (years) }\end{array}$ & $<5$ & 5 to 10 & 11 to 15 & 16 to 20 & 21 to 25 & 26 to 30 & 31 to 35 & $>35$ \\
\hline Percentage & 4.2 & 18.8 & 18.8 & 14.6 & 18.8 & 10.4 & 8.3 & 6.3 \\
\hline $\begin{array}{l}\text { Number of } \\
\text { projects }\end{array}$ & $<5$ & 5 to 15 & 16 to 25 & 26 to 35 & 36 to 45 & \multicolumn{2}{|c|}{46 to 55} & $>55$ \\
\hline Percentage & 8.3 & 27.1 & 20.8 & 16.7 & 12.5 & \multicolumn{2}{|l|}{8.3} & 6.2 \\
\hline Position & \multicolumn{2}{|c|}{ Project manager } & \multicolumn{2}{|c|}{ Contract manager } & Executive dire & \multicolumn{3}{|c|}{ Construction manager } \\
\hline Percentage & \multicolumn{2}{|l|}{39.6} & \multicolumn{2}{|l|}{31.3} & 14.6 & \multicolumn{2}{|c|}{14.6} & \\
\hline
\end{tabular}

\section{Interview parts}

The interview questions comprised four parts, and established: (i) participant levels of risk aversion; (ii) the effect of level of risk aversion and the contribution level of agents in the project on the monetary time incentive/disincentive for agents; and (iii) the effect of actual time uncertainty and the effect of level of risk aversion on monetary time incentive for team.

\section{(i) Participant levels of risk aversion}

The participants were interviewed to measure their levels of risk-aversion, based on certainty equivalence (Clemen and Reilly, 2001). The interview presented the decision maker (contractor) with a hypothetical, uncertain contract with a 50:50 chance of either gaining $\alpha$ Tc or losing half of that amount. $\alpha$ is a constant which varies between 0 and 1 ; and Tc is the target estimate of the work that they typically carry out. The value of $\alpha$ is adjusted during the interview. The largest value of $\alpha \mathrm{Tc}$ is approximately equal to the decision maker's risk tolerance. The inverse of the risk tolerance equals the level of risk aversion. The participants were asked to consider an uncertain contract with a target cost kept constant at $\$ 10 \mathrm{M}$. Due to the affect the economic situation may have on their responses, the participants were asked to make decisions based on a normal economic situation and normal workload; this is because, for example, if the contractor has a heavy work load or is almost out of work, it may have a different level of risk aversion (Willenbrock, 1973).

\section{(ii) Monetary time incentive/disincentive for agents}

For a fee defined as in Equation (1), the participants were asked to choose the desired value of sharing ratio, $\mathrm{s}_{\mathrm{i}}$, where they play the role of Agent A in a consortium of two agents. Three scenarios were designed, based on the contribution level of Agent A in the project, compared with that for Agent B: namely $\psi_{1}=\psi_{2} ; \psi_{1}>\psi_{2}$; and $\psi_{1}<\psi_{2}$. In the cases where $\psi_{1}>\psi_{2}$ 
and $\psi_{1}<\psi_{2}$, the agents were told to make decisions based on ratios of $\psi_{1}$ to $\psi_{2}$ of $60 / 40$ and 40/60, respectively.

\section{(iii) Monetary time incentive for teams}

For a fee defined as in Equation (2), the participants were asked to choose a desired team's monetary value of time underrun/overrun (incentive/disincentive ratio), $\mathrm{s}$, and a desired team tendered fee, F, assuming they were Agent A in a team of two similar agents. The agents were required to make their decisions in four different uncertainty scenarios. Each scenario provided the participants with different levels of uncertainty in the monetary value of time underrun/overrun of the work due to events outside of the contractor's influence, as shown in Table 3. This table presents the variances of the monetary value of time underrun/overrun, $\sigma^{2}$, calculated by using the PERT-style.

Table 3: Uncertainty level due to events outside the contractor's influence

\begin{tabular}{|c|c|c|c|c|}
\hline & \multicolumn{4}{|c|}{ Monetary value of time overrun/underrun } \\
\hline $\begin{array}{l}\text { Uncertainty } \\
\text { level }\end{array}$ & Pessimistic (overrun) & Most likely & $\begin{array}{l}\text { Optimistic } \\
\text { (underrun) }\end{array}$ & $\frac{\sigma^{2}}{T^{2}}$ \\
\hline Very low & $-0.05 \mathrm{Tc}$ & 0 & $0.05 \mathrm{Tc}$ & 0.0003 \\
\hline Low & $-0.10 \mathrm{Tc}$ & & $0.10 \mathrm{Tc}$ & 0.0011 \\
\hline Usual & $-0.15 \mathrm{Tc}$ & & $0.15 \mathrm{Tc}$ & 0.0025 \\
\hline High & $-0.25 \mathrm{Tc}$ & & $0.25 \mathrm{Tc}$ & 0.0070 \\
\hline Very high & $-0.30 \mathrm{Tc}$ & & $0.30 \mathrm{Tc}$ & 0.0100 \\
\hline
\end{tabular}

\section{Empirical study - results}

\section{Participant levels of risk aversion}

The results of risk aversion measurement, shown in Figure 1, reveal that the level of risk aversion among the participants varies between 5 (least averse) and 33.3 (most averse) as the proportion of the target cost estimate of the work that they typically carry out.

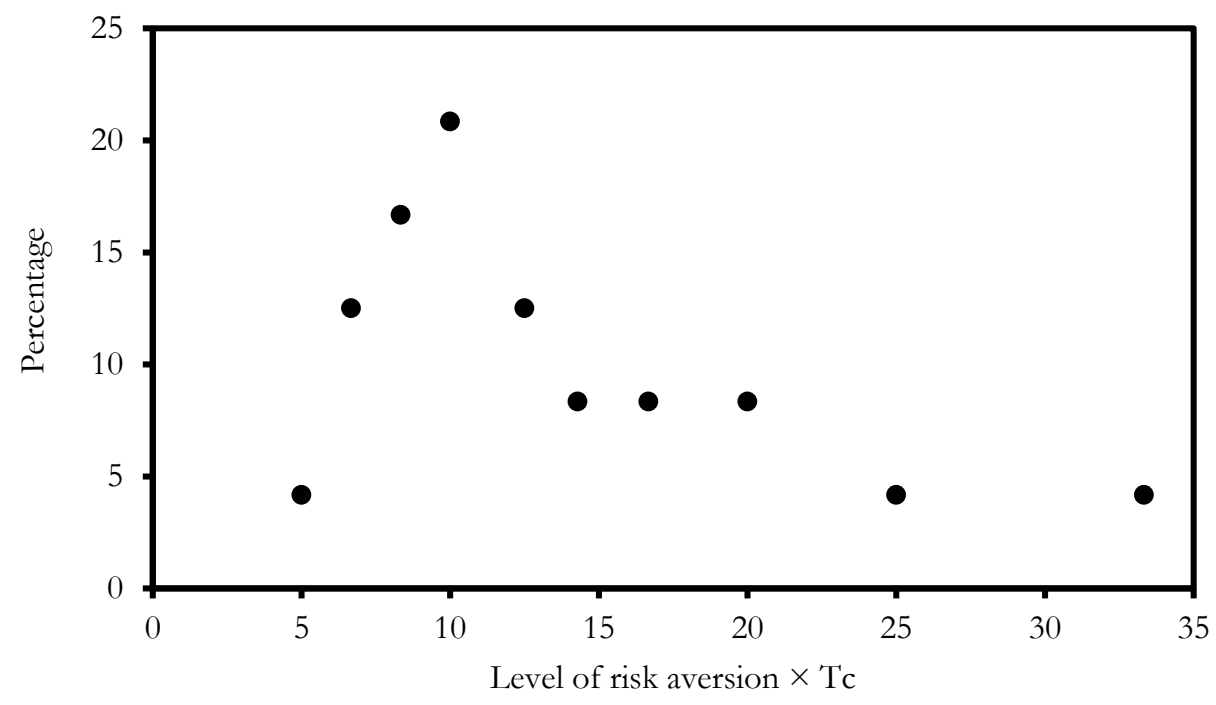

Figure 1: Risk attitudes of the sample of agents 


\section{Monetary time incentive/disincentive for agents}

Table 4 shows the average sharing ratio values selected by risk-averse contractors when they play the role of Contractor A. This table shows the average sharing ratio values selected by risk-averse contractors when they play the role of Contractor A. For example, the first row of Table 4 illustrates that the participants with level of risk aversion, $\eta$, equals to $33.33 /$ Tc selected on average $0.20,0.10$ and 0.05 sharing ratio values in cases $\psi_{1}>\psi_{2}, \psi_{1}=\psi_{2}$ and $\psi_{1}<\psi_{2}$, respectively, for Contractor A. In this table the symbol $\psi_{i}$ represents the contribution of contractor $\mathrm{i}$ towards the project completion time. The ranking of sharing ratio values selected by contractors with the same level of risk aversion, from high to low respectively, belong to the cases where $\psi_{1}>\psi_{2}, \psi_{1}=\psi_{2}$ and $\psi_{1}<\psi_{2}$. This implies that risk-averse contractors prefer a high sharing ratio value in a consortium of two contractors when they have a higher contribution level towards the actual time compared to the other contractor. This supports the validity of Proposition 1. This result is consistent with Chang (2013) who asserts that any time incentive/disincentive arrangement should be based on a real ability of a party (agent) to manage and mitigate the risk.

Table 4: Sharing ratio for Agent A selected by participants

\begin{tabular}{|llll|}
$\eta \times \mathrm{Tc}_{\mathrm{c}}$ & $\psi_{1}>\psi_{2}$ & $\psi_{1}=\psi_{2}$ & $\psi_{1}<\psi_{2}$ \\
\hline $\mathbf{3 3 . 3 3}$ & 0.20 & 0.10 & 0.05 \\
\hline $\mathbf{2 5 . 0 0}$ & 0.23 & 0.13 & 0.08 \\
\hline $\mathbf{2 0 . 0 0}$ & 0.20 & 0.13 & 0.05 \\
\hline $\mathbf{1 6 . 6 7}$ & 0.29 & 0.18 & 0.09 \\
\hline $\mathbf{1 4 . 2 9}$ & 0.25 & 0.15 & 0.10 \\
\hline $\mathbf{1 2 . 5 0}$ & 0.35 & 0.24 & 0.12 \\
\hline $\mathbf{1 0 . 0 0}$ & 0.34 & 0.24 & 0.12 \\
\hline $\mathbf{8 . 3 3}$ & 0.35 & 0.26 & 0.14 \\
\hline $\mathbf{6 . 6 7}$ & 0.43 & 0.28 & 0.16 \\
\hline $\mathbf{5 . 0 0}$ & 0.45 & 0.30 & 0.18 \\
\hline
\end{tabular}

Table 4 also supports the validity of the theoretical results in terms of the relationship between an agent's share of monetary value of time underrun/overrun (incentive/disincentive) and the level of risk aversion in a consortium (Equation 19). It shows that an increase in the value of $\mathrm{s}_{1}$ follows from a decrease in level of risk aversion. This supports the validity of Proposition 2. This result is consistent with Ward et al. (1991) who argues that "allocation should be based on the willingness of parties to take on a risk". This result is also supported by the alliance literature. For example, Ross (2006) argues that a sharing arrangement, which may be suitable for one project, is unlikely to be appropriate for another project due to differences in an agent's risk appetite. In the same vein, Al-Subhi Al-Harbi (1998) suggests that the agent needs to be open about its risk attitude and, in particular, its level of risk aversion. This will assist the principal and agent in reaching agreement on the optimal time sharing.

For level of risk aversion, $\eta$, indicator variables $\mathrm{y}_{1}$ and $\mathrm{y}_{2}$ (coding defined in Table 5), and constant coefficients $\alpha_{0}, \alpha_{1}, \alpha_{2}$ and $\alpha_{3}$, a regression equation of the following form can be described:

$$
\mathrm{s}_{1}=\alpha_{0}+\alpha_{1}(\eta \times \mathrm{Tc})+\alpha_{2} \mathrm{y}_{1}+\alpha_{3} \mathrm{y}_{2}
$$


Table 5: Coding for indicator variables $\mathrm{x}_{1}$ and $\mathrm{x}_{2}$

\begin{tabular}{|lll|}
\hline Contribution comparison & $\mathrm{y}_{1}$ & $\mathrm{y}_{2}$ \\
\hline$\psi_{1}>\psi_{2}$ & 1 & 0 \\
\hline$\psi_{1}=\psi_{2}$ & 0 & 0 \\
\hline$\psi_{1}<\psi_{2}$ & 0 & 1 \\
\hline
\end{tabular}

The best fit results using Table 4 data are shown in Table 6. For the overall regression, the coefficient of determination, $\mathrm{R}^{2}$, equals 0.83 with a $\mathrm{p}$-value of 0.000 . The low $\mathrm{p}$-value indicates statistical significance, and the results are unlikely to have occurred by chance, thereby supporting the reliability of the regression results (Montgomery et al., 2012). Accordingly, the effects of risk aversion and agents' contribution in the project on $\mathrm{s}_{1}$ are significant. This provides further support for Propositions 1 and 2.

Table 6: Regression results for Equation (22)

\begin{tabular}{|l|l|l|l|l|}
\hline & $\alpha_{0}$ & $\alpha_{1}$ & $\alpha_{2}$ & $\alpha_{3}$ \\
\hline Value & 0.31 & -0.008 & 0.108 & -0.103 \\
\hline
\end{tabular}

\section{Monetary time incentive for team}

The corresponding results of monetary time incentive for team are outlined in Tables 7 and 8 and graphically shown in Figures 2 and 3.

Table 7: Agents team's average sharing ratio values selected by the risk-averse participants

\begin{tabular}{|llllllllllll|}
$\frac{\sigma^{2}}{\mathrm{Tc}}$ & 5 & 6.7 & 8.3 & 10 & 12.5 & 14.3 & 16.7 & 20 & 25 & 33.3 \\
\hline $\mathbf{0 . 0 0 0 3}$ & 0.95 & 0.89 & 0.88 & 0.83 & 0.81 & 0.69 & 0.66 & 0.56 & 0.5 & 0.55 \\
\hline $\mathbf{0 . 0 0 1 1}$ & 0.75 & 0.72 & 0.63 & 0.65 & 0.63 & 0.49 & 0.49 & 0.39 & 0.33 & 0.35 \\
\hline $\mathbf{0 . 0 0 2 5}$ & 0.6 & 0.56 & 0.52 & 0.49 & 0.48 & 0.33 & 0.35 & 0.26 & 0.2 & 0.2 \\
\hline $\mathbf{0 . 0 0 7}$ & 0.45 & 0.4 & 0.42 & 0.35 & 0.34 & 0.21 & 0.25 & 0.16 & 0.1 & 0.13 \\
\hline $\mathbf{0 . 0 1}$ & 0.4 & 0.3 & 0.35 & 0.25 & 0.28 & 0.18 & 0.2 & 0.1 & 0.05 & 0.05 \\
\hline
\end{tabular}

Table 8: Agents team's average fixed fee/Tc values selected by the risk-averse participants

\begin{tabular}{|lllllllllll|}
$\frac{\sigma^{2}}{\mathrm{Tc}}$ & 5 & 6.7 & 8.3 & 10 & 12.5 & 14.3 & 16.7 & 20 & 25 & 33.3 \\
\hline $\mathbf{0 . 0 0 0 3}$ & 0.07 & 0.07 & 0.07 & 0.07 & 0.08 & 0.09 & 0.09 & 0.11 & 0.11 & 0.12 \\
\hline $\mathbf{0 . 0 0 1 1}$ & 0.08 & 0.08 & 0.08 & 0.09 & 0.09 & 0.11 & 0.1 & 0.12 & 0.12 & 0.13 \\
\hline $\mathbf{0 . 0 0 2 5}$ & 0.1 & 0.1 & 0.11 & 0.11 & 0.1 & 0.12 & 0.12 & 0.13 & 0.13 & 0.13 \\
\hline $\mathbf{0 . 0 0 7}$ & 0.11 & 0.11 & 0.12 & 0.12 & 0.12 & 0.13 & 0.14 & 0.15 & 0.15 & 0.15 \\
\hline $\mathbf{0 . 0 1}$ & 0.12 & 0.13 & 0.13 & 0.13 & 0.14 & 0.15 & 0.16 & 0.16 & 0.16 & 0.17 \\
\hline
\end{tabular}




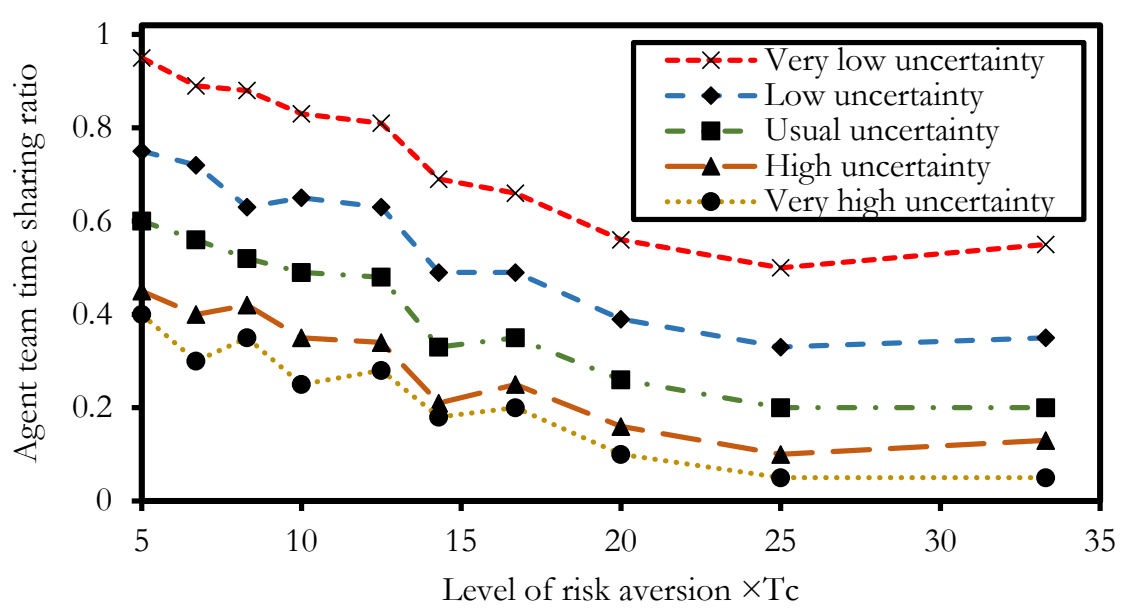

Figure 2: Agent team time incentive/disincentive sharing ratio

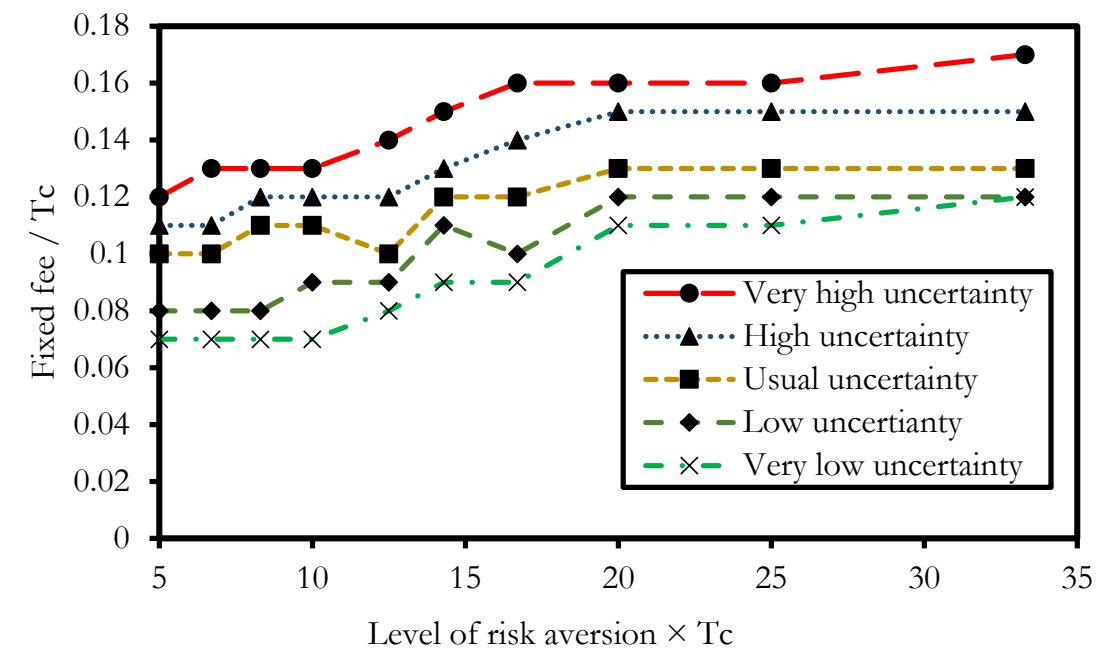

Figure 3: Agent team fixed fee

Figure 2 shows the consortium's average share of monetary value of time underrun/overrun selected by the risk-averse contractors. The results show that an increase in the level of actual cost uncertainty leads to a decrease in the value of s selected by the contractors, reflecting the contractors' concerns. This supports the validity of Proposition 3a. Chang (2013) states that risk sharing should be based on a reasoned assessment of risk and return trade-offs. Figure 2 also demonstrates that an increase in the value of $\mathrm{s}$ follows from a decrease in the level of risk aversion. This supports the validity of Proposition 3b.

The consortium's average fixed fee values are illustrated in Figure 3, and present an opposing trend to Figure 2. An increase in the fixed fee follows from an increase in the level of time underrun/overrun uncertainty, reflecting the contractors' concerns about uncertainty in the actual time of the work. This supports the validity of Proposition 4a. Figure 3 also demonstrates that an increase in the value of $\mathrm{s}$ follows from a decrease in the level of risk aversion. This supports the validity of Proposition 5b.

Using regression equations of the form,

$$
\mathrm{n}=\beta_{0}+\beta_{1}(\eta \times \mathrm{Tc})+\beta_{2}\left(\frac{\mathrm{k} \sigma}{\mathrm{Tc}}\right)
$$




$$
\mathrm{F}=\delta_{0}+\delta_{1}(\eta \times \mathrm{Tc})+\delta_{2}\left(\frac{\mathrm{k} \sigma}{\mathrm{Tc}}\right)
$$

where $\sigma$ is actual time standard deviation, and $\beta_{0}, \beta_{1}, \beta_{2}, \delta_{0}, \delta_{1}$ and $\delta_{2}$ are constant coefficients, the best fit regression results using Tables 7 and 8 data are shown in Tables 9 and 10, respectively with a $\mathrm{p}$-value of 0.000 . The low p-value shows that the effects of time uncertainty and risk aversion on the team's monetary value of time underrun/overrun and the team's fixed fee are significant (Montgomery et al., 2012), providing further support for propositions 3 and 4.

Table 9: Regression results for Equation (23)

\begin{tabular}{|l|l|l|l|}
\hline & & Coefficient & \\
\hline & $\beta_{0}$ & $\beta_{1}$ & $\beta_{2}$ \\
\hline Value & 0.93 & -0.02 & -5.2 \\
\hline
\end{tabular}

Table 10: Regression results for Equation (24)

\begin{tabular}{|l|l|l|l|}
\hline & & Coefficient & \\
\hline & $\delta_{0}$ & $\delta_{1}$ & $\delta_{2}$ \\
\hline Value & 0.054 & 0.002 & 0.625 \\
\hline
\end{tabular}

\section{Recommendations}

Based on the paper's analysis and data, it is possible to provide quantitative advice on the choice of ratios. In the cumulative frequency plot, Figure 4 using Figure 1 data, the level of risk aversion for the sample agents (contractors) is classified into three groups: low, medium and high. The classification is based on quartiles, giving a low risk aversion lying between 5.0/Tc and 7.5/Tc, a medium risk aversion between $7.5 / \mathrm{Tc}$ and $14.3 / \mathrm{Tc}$, and a high risk aversion between $14.3 / \mathrm{Tc}$ and 33.3/Tc.

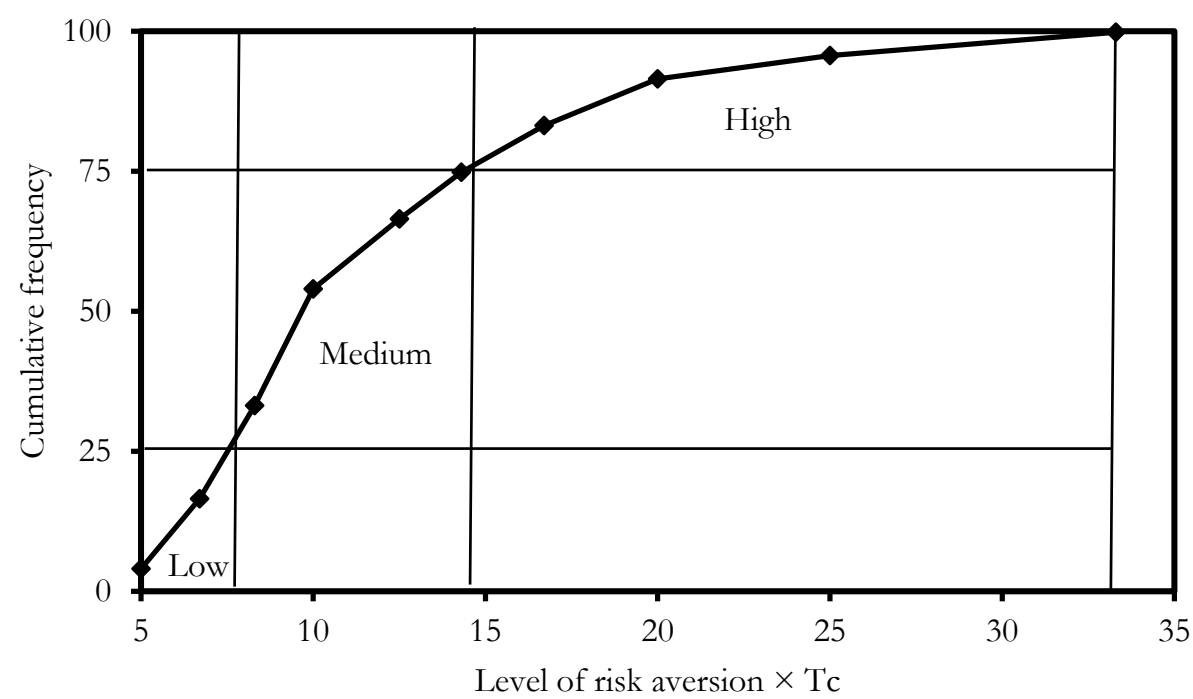

Figure 4: Distribution of the level of risk aversion between sample agents

The results that follow are relatively insensitive to the choice of boundaries between low, medium and high risk aversion; the boundaries can change by $\pm 10 \%$ in the level of risk aversion without changing the recommendations. 


\section{Time incentive/disincentive sharing among two agents}

By calculating the average sharing ratios, taken from Tables 4 and 7 data, for the risk aversion classification, presented in Figure 4, recommended values of time incentive/disincentive sharing among two agents were obtained. These are summarized in Table 11 for five levels of time uncertainty, 'very low', 'low', 'usual', 'high' and 'very high' as defined in Table 3.

In Table 11 the sharing ratio varies from 0.71 to 0.03 . The highest sharing ratio $(n=0.71)$ needs to be used in order to work with very low uncertainty (well defined projects), where a low riskaverse agent with a high contribution is engaged. By contrast, the lowest sharing ratio $(\mathrm{n}=0.03)$ needs to be offered to a high risk-averse agent with a low contribution in a very high time uncertainty work (poor defined projects, or projects involved new technologies). Previous research has omitted the effect of the agent contribution, time uncertainty and risk aversion simultaneously on an optimal time sharing with a team of agents. For example, Sakal (2005) and Love et al., (2011) suggest that any gain/pain should be spread 50:50 between the principal and agent in alliance projects. With a high sharing ratio, the contract corresponds to a fixed-price (lump sum or schedule of rates) contract and with a low sharing ratio the contract corresponds to a cost-reimbursement contract in practice. Accordingly, fixed-price contracts should be used in very low uncertain projects and cost-reimbursement contracts should be employed in very high uncertain projects. This is consistent with Eisenhardt's (1989) study who believes that for work where the outcome has a low level of uncertainty, the outcome-based contract is more attractive, compared to work with a high level of uncertainty, where a behaviour-based contract is considered more attractive.

Table 11: Recommended values of agent time incentive/disincentive sharing ratio in a team of two agents

\begin{tabular}{|c|c|c|c|c|}
\hline \multirow{2}{*}{$\begin{array}{l}\text { Uncertainty } \\
\text { level }\end{array}$} & \multirow{2}{*}{$\begin{array}{l}\text { Contribution } \\
\text { comparison }\end{array}$} & \multicolumn{3}{|c|}{ Risk aversion level } \\
\hline & & Low & Medium & High \\
\hline \multirow[t]{3}{*}{ Very low } & Lower & 0.20 & 0.22 & 0.16 \\
\hline & Same & 0.45 & 0.41 & 0.29 \\
\hline & Higher & 0.71 & 0.60 & 0.42 \\
\hline \multirow[t]{3}{*}{ Low } & Lower & 0.16 & 0.17 & 0.11 \\
\hline & Same & 0.36 & 0.31 & 0.20 \\
\hline & Higher & 0.57 & 0.45 & 0.30 \\
\hline \multirow[t]{3}{*}{ Usual } & Lower & 0.13 & 0.13 & 0.07 \\
\hline & Same & 0.29 & 0.24 & 0.14 \\
\hline & Higher & 0.44 & 0.35 & 0.20 \\
\hline \multirow[t]{3}{*}{ High } & Lower & 0.09 & 0.09 & 0.05 \\
\hline & Same & 0.21 & 0.17 & 0.09 \\
\hline & Higher & 0.32 & 0.25 & 0.13 \\
\hline \multirow[t]{3}{*}{ Very high } & Lower & 0.07 & 0.07 & 0.03 \\
\hline & Same & 0.16 & 0.14 & 0.06 \\
\hline & Higher & 0.25 & 0.20 & 0.09 \\
\hline
\end{tabular}

In a situation where there is no information about the agent's level of risk aversion and only general information about the level of contribution and time uncertainty exists, practitioners will find Table 12 useful for determining a suitable value for the sharing ratio. This table summarizes the average sharing ratio for each level of time uncertainty and the agent contribution presented in Table 11. 
Table 12: Recommended values of agent time incentive/disincentive sharing ratio in a team of two agents for different levels of time uncertainty and agent contribution.

\begin{tabular}{|c|c|c|c|}
\hline \multirow[t]{2}{*}{$\begin{array}{l}\text { Uncertainty } \\
\text { level }\end{array}$} & \multicolumn{3}{|c|}{$\begin{array}{l}\text { Contribution } \\
\text { comparison }\end{array}$} \\
\hline & Lower & Same & Higher \\
\hline Very low & 0.19 & 0.38 & 0.57 \\
\hline Low & 0.15 & 0.29 & 0.44 \\
\hline Usual & 0.11 & 0.21 & 0.31 \\
\hline High & 0.08 & 0.16 & 0.24 \\
\hline Very hi & 0.06 & 0.12 & 0.18 \\
\hline
\end{tabular}

\section{Example usage}

An example is presented to demonstrate how a time sharing formula can be established in any given situation. Consider a project with two agents, namely Agent A and Agent B, where the agent's fee is defined as in Equation (1). Assume, for a given project, that the utility assessments reveal that Agent A and Agent B are both risk-averse with, respectively, 8.33/Tc and 20/Tc levels of risk aversion. By using data presented in Figure 4 and Table 11, recommended values of the time sharing ratio, si, for the given agents can be obtained. These are summarized in Table 13 for three levels of time uncertainty, 'low', 'usual' and 'high', as defined in Table 3.

Table 13: Values of time incentive/disincentive sharing ratio for the given example agents

\begin{tabular}{|c|c|c|c|c|c|c|}
\hline \multirow[t]{2}{*}{ Case } & \multirow{2}{*}{$\begin{array}{l}\text { Uncertainty } \\
\text { level }\end{array}$} & \multicolumn{2}{|c|}{ Contribution } & \multicolumn{2}{|c|}{ Sharing ratio } & \multirow{2}{*}{$\begin{array}{l}\text { Team } \\
\text { sharing } \\
\text { ratio }\end{array}$} \\
\hline & & Agent A & Agent B & Agent A & Agent B & \\
\hline 1 & \multirow[t]{3}{*}{ Low } & Low & High & 0.17 & 0.30 & 0.47 \\
\hline 2 & & Same & Same & 0.31 & 0.20 & 0.51 \\
\hline 3 & & High & Low & 0.45 & 0.11 & 0.56 \\
\hline 4 & \multirow[t]{3}{*}{ Usual } & Low & High & 0.13 & 0.20 & 0.33 \\
\hline 5 & & Same & Same & 0.24 & 0.14 & 0.38 \\
\hline 6 & & High & Low & 0.35 & 0.07 & 0.42 \\
\hline 7 & \multirow[t]{3}{*}{ High } & Low & High & 0.09 & 0.13 & 0.22 \\
\hline 8 & & Same & Same & 0.17 & 0.09 & 0.26 \\
\hline 9 & & High & Low & 0.25 & 0.05 & 0.30 \\
\hline
\end{tabular}

A similar approach can be adopted for other agents and other project situations by using the data in Figure 4 and Table 11.

\section{Conclusion}

This paper derived the optimal form of a time incentive/disincentive-based compensation in contracts with a team of agents through extending principal-agent theory. The paper demonstrated that the proportion of monetary value of time incentive/disincentive among agents with the same risk-attitude should be higher for agents with a higher contribution to the project. The paper also demonstrated that the proportion of monetary value of time incentive/disincentive sharing among agents with the same level of contribution should be lower for agents with higher levels of risk aversion. In addition, the paper showed that the proportion of monetary value of time incentive/disincentive to a team of agents should reduce and the fixed component of the team fee should increase when the agents within the team become more riskaverse or the level of the time uncertainty increases. The shape of the time incentive contract derived here is optimal under defined assumptions such as linear payments, agents risk aversion 
and principal risk neutrality. The empirical results obtained provide highly persuasive evidence and support for the paper's theoretical development.

This paper gives an original solution to the optimal time incentive/disincentive problem with a team of agents, contributing to current practices in contracts management. Typically, construction literature are survey-based with little intention to test hypotheses derived from theories. This research applies the principal-agent theory to the analysis of optimal incentive/disincentive contracts in construction to address the theoretical void. Principals and agents might have a general idea about risk sharing and agent motivation; however their decisions on contract form, at present, are not based on any rigorous model or theory. Setting risk transfer at the right level can potentially result in cost savings and ignoring an optimal risk sharing may lead the principal to misuse incentives. The principal may lose more than the agents in the event of project disruption, as it is vulnerable to holdup demands in renegotiations and the principal may incur more transaction costs in resolving disputes. The paper's outcome provides guidance to those involved in designing contracts for choosing the best way to reward/penalize multiple agents, forming a team, through the terms of a contract for any time underrun/overrun. Where the time incentive contract is the subject of negotiation, the insight from this paper should assist the contracting parties in that negotiation. Although the primary reference is to construction projects, the solutions presented here apply equally well to related project types. The theoretical results were supported through conducting an empirical study based on interviewing a sample of mediumsized contractors in the commercial and building fields, and hence the support for the theoretical results is limited to similar situations, until further data has been assembled.

A number of extensions to the present paper are possible; for example, multi-period contracts. These contracts move beyond the static model discussed here towards dynamic models that are enforced by the parties' concerns for their reputations. Another extension is to consider the effect of the repeated relationship and career concerns on the time incentive arrangements. This paper presents the optimal sharing arrangement for the one-principal case. Further extension could be made to develop a contract with multiple principals. Another possible extension would be to consider a survey or questionnaire to capture industry professionals' concerns about the outcomes of this research. It is acknowledged that there may exist parameters affecting the selection of the optimal time incentive contract other than those considered in this paper, and this creates the potential for future research.

\section{References}

Al-Subhi Al-Harbi, K.M. (1998) Sharing fractions in cost-plus-incentive-fee contracts. International Journal of Project Management, 16(2), p.73-80 doi: https://doi.org/10.1016/S0263-7863(97)00013-6

Arditi, D. and Yasamis, F. (1998) Incentive/disincentive contracts: perceptions of owners and contractors. Journal of Construction Engineering and Management, 124(5), p. 361-73 doi: https://doi.org/10.1061/(asce)07339364(1998)124:5(361)

Badenfelt, U. (2008) The selection of sharing ratios in target cost contracts. Engineering, Construction and Architectural Management, 15(1), pp. 54-65 doi: https://doi.org/10.1108/09699980810842061

Barnes, M. (1983) How to allocate risks in construction contracts. International Journal of Project Management, 1(1), p.24 28 doi: https://doi.org/10.1016/0263-7863(83)90034-0

Basu, A.K. and. Kalyanaram, G. (1990) On the relative performance of linear versus nonlinear compensation plans. International Journal of Research in Marketing, 7, p.171-179. doi: https://doi.org/10.1016/0167-8116(90)90019-J

Bower, D., Ashby, G., Gerald, K. and Smyk, W. (2002) Incentive mechanisms for project success. Journal of Management in Engineering, ASCE, 18(1), p.37-43. doi: https://doi.org/10.1061/(ASCE)0742597X(2002)18:1(37)

Bresnen, M., and Marshall, N. (2000) Motivation, commitment and the use of incentives in partnerships and alliances. Construction Management and Economics, 18(5), p.587-598 doi: https://doi.org/10.1080/014461900407392

Broome, J., and Perry, J. (2002) How practitioners set share fractions in target cost contracts. International Journal of Project Management, 20(1), p.59-66. doi: https://doi.org/10.1016/S0263-7863(00)00035-1 
Chan, J.H.L., Chan, D.W.M., Lam, P.T.I., and Chan, A.P.C. (2011) Preferred risk allocation in target cost contracts in construction. Facilities, 29(13/14), p.542-562. doi: https://doi.org/10.1108/02632771111178364

Change, C. (2013) Principal-agent model of risk allocation in construction contracts and its critique. Journal of Construction Engineering and Management, 140(1), p. 1-19 doi: https://doi.org/10.5465/AMBPP.2013.12523abstract

Chang, C.Y. (2013) Understanding the hold-up problem in the management of megaprojects: The case of the channel tunnel rail link project. International Journal of Project Management, 31(4), p.628-637. doi: https://doi.org/10.1016/j.ijproman.2012.10.012

Clemen, R.T. and Reilly, T. (2001) Making hard decisions with decision tools. Duxbury Pacific Grove, Calif., Duxbury/Thomson Learning.

Coughlan, A.T. and Sen, S. K. (1989) Salesforce compensation: Theory and managerial implications. Marketing Science, 8(4), p.324-342. doi: https://doi.org/10.1287/mksc.8.4.324

Eisenhardt, K.M. (1989) Agency theory: An assessment and review. The Academy of Management Review, 14(1), pp. 57-74. doi: https://doi.org/10.5465/AMR.1989.4279003 and https://doi.org/10.2307/258191

Holmstrom, B. (1979) Moral hazard and observability. The Bell Journal of Economics, 10(1), p.74-91 doi: https://doi.org/10.2307/3003320

Holmstrom, B., and Milgrom, P. (1987) Aggregation and linearity in the provision of intertemporal incentives. Econometrica, 55(2), p.303-328. doi: https://doi.org/10.2307/1913238

Hosseinian, S.M., and Carmichael D.G. (2013a) An optimal incentive contract with a risk-neutral contractor, Journal of Construction Engineering and Management, 139(8), p.899-909. doi: https://doi.org/10.1061/(ASCE)CO.1943$\underline{7862.0000663}$

Hosseinian, S.M., and Carmichael, D.G. (2013b) Optimal gainshare/painshare in alliance projects. Journal of the Operational Research Society, 64(8), p.1269-1278. doi: https://doi.org/10.1057/jors.2012.146

Hosseinian, S.M., and Carmichael, D.G. (2014) Optimal sharing arrangement for multiple project outcomes. Journal of Financial Management of Property and Construction, 19(3), p.264-280. doi: https://doi.org/10.1057/jors.2012.146

Hughes, D., Williams, T. and Ren, Z. (2012) Is incentivisation significant in ensuring successful partnered projects? Engineering, Construction and Architectural Management, 19(3), p.306-319. doi: https://doi.org/10.1108/09699981211219625

Jaraiedi, M., Plummer, R.W., and Aber, M.S. (1995) Incentive/disincentive guidelines for highway construction contracts. Journal of Construction Engineering and Management, 121(1), p.112-120. doi: https://doi.org/10.1061/(ASCE)0733-9364(1995)121:1(112)

Laffont, J., and Martimort, D. (2001) The theory of incentives: The principal-agent model, Princeton University Press, Princeton, NJ.

Lambert, R. (2001) Contracting theory and accounting. Journal of Accounting and Economics, 32(1), p.3-87. doi: https://doi.org/10.1016/S0165-4101(01)00037-4

Love, P.E.D., Davis, P.R., Chevis, R., and Edwards, D.J. (2011) Risk/reward compensation model for civil engineering infrastructure alliance projects. Journal of Construction Engineering and Management, 137(2), p. 127-136. doi: https://doi.org/10.1061/(ASCE)CO.1943-7862.0000263

McGeorge, D. and Palmer, A. (2002) Construction management new directions, 2nd, Oxford, Blackwell Science.

Montgomery, D.C., Runger, G.C., and Hubele, N.F. (2012) Engineering statistics, John Wiley and Sons, Asia.

National Audit Office. (2009) The failure of Metronet, London. available at: doi: https://www.nao.org.uk/wpcontent/uploads/2009/06/0809512.pdf, accessed 10 May 2016.

Perry, J.G. and Barnes, M. (2000) Target cost contracts: an analysis of the interplay between fee, target, share and price. Engineering Construction and Architectural Management, 7(2), p.202-208. doi: https://doi.org/10.1108/eb021145.

Petersen, T. (1993) The economics of organization: The principal-agent relationship. Acta Sociologica, 6(3), p.277-93. doi: https://doi.org/10.1177/000169939303600309

Rahman, M.M., and Kumaraswamy, M.M. (2005) Assembling integrated project teams for joint risk management. Construction Management and Economics, 23(4), pp. 365-375. doi: https://doi.org/10.1080/01446190500040083

Raju, J.S. and Srinivasan, V., 1996. Quota-based compensation plans for multiterritory heterogeneous salesforces. Management Science, 42(10), p.1454-1462. doi: https://doi.org/10.1287/mnsc.42.10.1454

Ross, J. (2006) Project alliancing practitioners' guide, Department of Treasury and Finance, available at: http://www.dtf.vic.gov.au, accessed 10 January 2015.

Sakal, M.W. (2005) Project alliancing: A relational contracting mechanism for dynamic projects. Lean Construction Journal, 2(1), p.67-79.

Sappington, D.E.M. (1991) Incentives in principal-agent relationships. Journal of Economic Perspectives, 5(2), p.45-66 doi: https://doi.org/10.1257/jep.5.2.45

Walewski, J., and Gibson, G. (2003) International project risk assessment: Methods, procedures, and critical factors. Rep. 31, Center for Construction Industry Studies, Univ. of Texas at Austin, Austin, TX.

Ward, S., and Chapman, C. (1994) Choosing contractor payment terms. International Journal of Project Management, 12(4), p.216-221. doi: https://doi.org/10.1257/jep.5.2.45. 
Weitzman, M.L. (1980) Efficient incentive contracts. The Quarterly Journal of Economics, 44(1), p.719-730. doi: https://doi.org/10.2307/1885665

Zhao, H. (2005) Incentive-based compensation to advertising agencies: A principal-agent approach. International Journal of Research in Marketing, 22(No) 3, p.255-275. doi: https://doi.org/10.1016/j.ijresmar.2004.10.002 